\title{
NOVÝ VÝSKYT MENILITOVÉHO SOUVRSTVÍ U DŘEVOHOSTIC
}

\author{
New occurrence of the Menilite Formation near Dřevohostice
}

\author{
Kamil Kropáč', Zdeněk Dolníček', Antonín Přichystal'², Tomáš Lehotský', \\ Tamara Koštuř́íková', Jiří Jakubál ${ }^{3}$ \\ ${ }^{1}$ Katedra geologie PřF UP v Olomouci, tř. 17. listopadu 12, 77146 Olomouc; e-mail: kamil.kropac@upol.cz \\ 2 Ústav geologických věd, Prírodovědecká fakulta, Masarykova univerzita, Kotlářská 2, 61137 Brno \\ ${ }^{3}$ Mlýnská 125, 75114 Drevohostice
}

(25-13 Přerov)

Key words: Outer Western Carpathians, Flysch Belt, Menilite Formation, laminated menilite chert

\begin{abstract}
The Menilite Formation is an important lithostratigraphic member of the Krosno-menilite Unit in the Carpathian Flysch Belt. The rocks of the Menilite Formation occur as small bodies also within Sub-Silesian Unit on the geological map sheet 25-13 Prerov. In this paper, we present new occurrence of chert layers of the Menilite Formation at ground elevation 275 which is situated $1.2 \mathrm{~km}$ easternly of the village Drevohostice. The rock body is formed of layers of laminated gray-white to gray-brown menilite chert interlayered by thin interpositions of weathered gray-green non-calcareous claystones. The menilite cherts consist of brownish-yellow and gray opal laminae with limonite and chalcedony streaks. Opal laminae have thickness mostly in range of 1-10 mm. Rock matrix is cut by numerous veins formed by opal and chalcedony which originated during at least two different events. Menilite cherts sporadically enclose small siliceous chalcedony geodes. Claystones have pelitic texture with a clotted inner structure and contain siliceous sponge spicules and other non-specified microfossils (probably planktonic diatoms). The cherty layers documented in a dug probe have WNW-ESE direction with inclination to SSW under the angle of $25^{\circ}$. The sediments were folded during the overthrust of the Sub-Silesian Nappe on the Carpathian Foredeep in the Karpatian and during subsequent late-tectonic rotations towards NW.
\end{abstract}

Úvod

Menilitové souvrství představuje významný litostratigrafický člen jednotek vnější skupiny př́krovů flyšového pásma Západních Karpat (Stráník 1981; Stráník et al. 1993). Menší výskyty menilitového souvrství byly zmapovány jako součást podslezské jednotky pracovníky ČGS i ve v. části geologické mapy ČR 1:50 000, list 25-13 Přerov (Pálenský 1996). K terénní dokumentaci byly použity zejména horninové úlomky získané z povrchového sběru, nebot mírně zvlněná krajina Kelčské pahorkatiny je charakteristická nedostatkem přirozených výchozů. Před několika lety nalezl jeden $\mathrm{z}$ autorů tohoto př́spěvku (J. Jakubál) úlomky laminovaných rohovců (menilitů) také na kótě 275 u Dřevohostic a spolu s nimi i větší množství křemitých geod vzhledově podobných známým rudickým koulím (Kropáč et al. 2014). Během výzkumu geod bylo zároveň získáno množství nových petrografických poznatků o horninách menilitového souvrství a díky odkrytí skalního podloží kopnými pracemi i o jejich úložných poměrech na lokalitě. Zmíněné poznatky předkládáme $\mathrm{v}$ této práci.

\section{Geologická pozice}

Studovaná oblast se nachází na styku karpatské předhlubně a flyšového pásma Západních Karpat. V širším okolí Dřevohostic vystupuje několik tektonických trosek, které byly přes řadu litologických podobností se ždánickou jednotkou tradičně řazeny $\mathrm{k}$ jednotce podslezské (např̀. Roth et al. 1963; Stráník et al. 1993; Pálenský 1996; Eliáš 1998; obr. 1). Tato jednotka představuje ve studované oblasti nejspodnější př́íkrov flyšového pásma složený z dílčích př́íkrovů či šupin s komplikova- nou vrásovou stavbou (Hanzlíková et al. 1953; Stráník et al. 1993; Eliáš 1998). Jurková (1976) rozlišila v podslezské jednotce dva hlavní př́krovy, které se přesouvaly v různých časových etapách. Starší př́krov byl nasunut na předhlubeň vyplněnou sedimenty karpatu ještě před započetím sedimentace ve spodním badenu, což je dobře patrné právě ve studované oblasti. Mladší vyšší prííkrov se pak nasouval na starší př́íkrov a karpatskou předhlubeň už s badenským sedimentárním pokryvem. Podslezská jednotka má na rozdíl od ostatních jednotek flyšových Karpat převážně neflyšový vývoj (Eliáš 1998). Nejstarší horniny podslezské jednotky v okolí Dřevohostic reprezentují pelity frýdlantského souvrství, které se usadily v intervalu paleocén až svrchní eocén (Stráník et al. 1993). Na frýdlantské souvrství nasedá menilitové souvrství (oligocén), jehož sedimentace probíhala $v$ batyálu ve špatně prokysličeném až anoxickém prostředí tethydního moře. Stráník et al. (1993) litologicky člení menilitové souvrství v klasickém vývoji ve ždánické jednotce na vrstvy podrohovcové, rohovcové, dynowské slínovce a vrstvy šitbořické. $\mathrm{V}$ podslezské jednotce souvislé profily menilitového souvrství chybějí, přesto lze i zde jednotlivé části tohoto souvrství paralelizovat s vývojem ve ždánické jednotce. Hnědé vápnité jílovce s příměsí prachu ve spodní části menilitového souvrství jsou litologicky identické s podrohovcovými vrstvami. Následují silicifikované lupenité jílovce a bělavě zvětrávající vápnité jílovce až jílovité vápence s proužky či čočkami tmavošedých rohovců. Tato sekvence je srovnávána s rohovcovými vrstvami a dynowskými slínovci ždánické jednotky. Jílovité vápence podle mikrofauny odpovídají spodnímu oligocénu. Nadložní různě zbarvené jílovce jsou jen vzácně slabě 

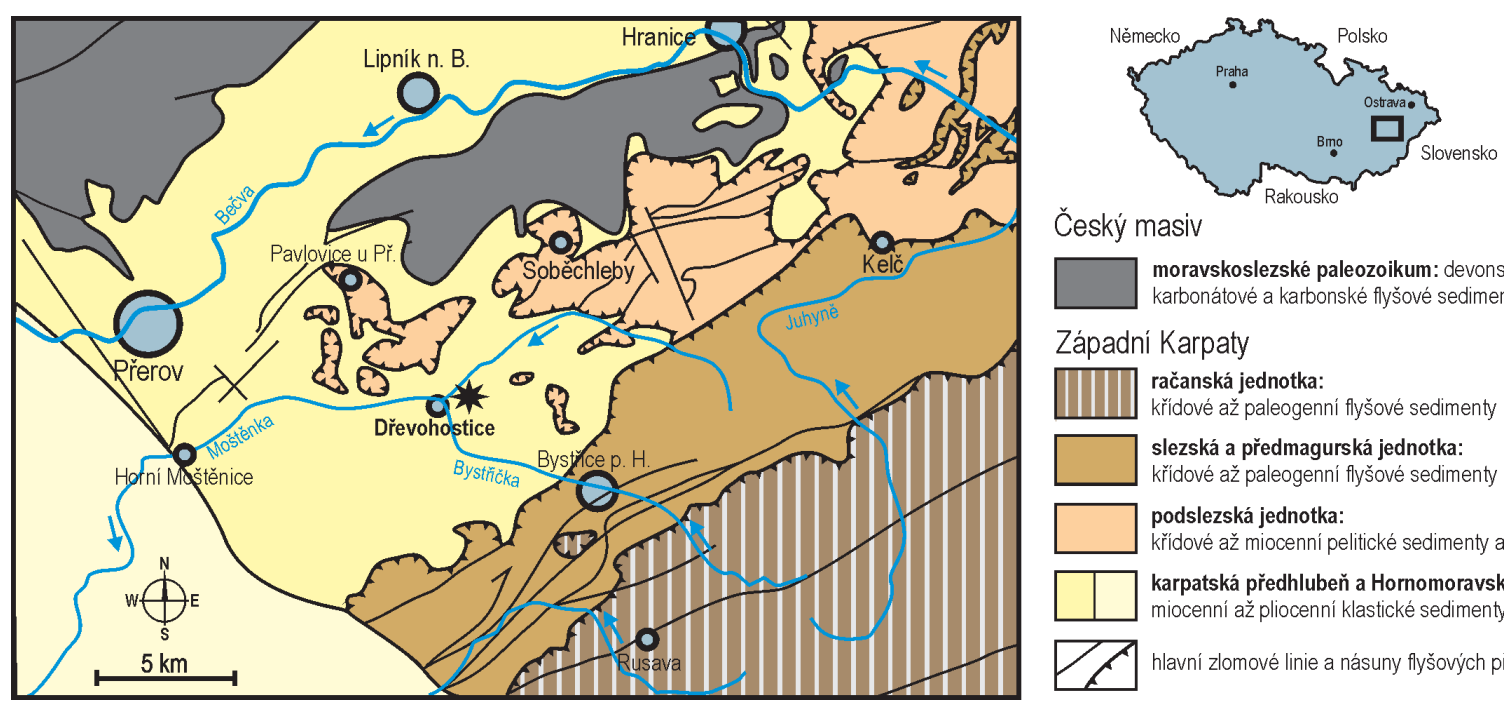

Český masiv

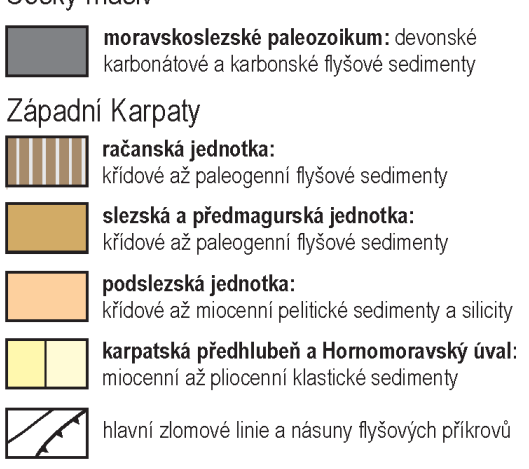

Obr. 1: Schematická mapa geologických jednotek na zájmovém území. Nový výskyt menilitového souvrství u Dřevohostic je označen hvězdičkou.

Fig. 1: Schematic map of geological units in the studied area. A new occurrence of the Menilite Formation near Dřevohostice is marked with an asterisk.

vápnité a obsahují vložky prachovců až jemnozrnných pískovců. Litologicky i biostratigraficky korespondují se šitbořickými vrstvami ždánické jednotky. Výše uvedené horniny menilitového souvrství byly v zájmovém území zmapovány v okolí obcí Čechy, Nahošovice, Oprostovice, Radkovy, Sovadina a Soběchleby (Pálenský 1996). Z paleontologického hlediska je celé souvrství významné výskyty oligocenní rybí fauny (např. Brzobohatý - Kalabis 1978; Kalabis 1981; Gregorová 1988; Přikryl 2009). Dříve se menilitové souvrství považovalo za nejvyšší člen podslezské jednotky, dnes se nad něj zařazuje ještě souvrství ženklavské egerského stáŕí (Eliáš 1998; Stráník, v tisku).

Ve spodním miocénu došlo před čely vrásnících se flyšových př́íkrovů $\mathrm{k}$ založení karpatské předhlubně. Pohyby ždánického a podslezského př́íkrovu v karpatu vyvolaly pokles předhlubně $\mathrm{v}$ oblasti $j$. a střední Moravy (Stráník et al. 1993). V okolí Dřevohostic se usadila klastika kroměřížského souvrství reprezentovaná vrstevnatými vápnitými jíly a jílovci („šlíry“), vápnitými písky se štěrky i různě zpevněnými vápnitými pískovci a slepenci s valouny flyšových hornin. Ve valounovém materiálu štěrků byly kromě křemene popsány také černé rohovce, rohovité vápence, mezozoické vápence, granitoidy a metamorfované horniny (Benada - Kokolusová 1987; Adámek et al. 2003). Nezpevněné psamity a psefity kroměřížského souvrství byly $\mathrm{v}$ minulosti na katastru Dřevohostic těženy v několika menších pískovnách. Jedna ze zaniklých pískoven je situována $250 \mathrm{~m}$ sz. od vrcholu kóty 275 při zářezu komunikace Dřevohostice-Radkovy. Horniny karpatu (,šlíry“) jsou v geologické mapě značeny také na studované lokalitě (Pálenský 1996). V nedalekých Dolních Nětčicích, ležících cca $8 \mathrm{~km}$ sv. od Dřevohostic, vystupují litorální sedimenty karpatu zastoupené žlutošedými až okrovými vápnitými pískovci s hojnými nálezy mořských měkkýšů, ramenonožců, svijonožců a zubů žralokủ (Čtyroký - Fejfar 1963). Transgrese ve spodním badenu zasáhla zájmové území pouze okrajově.

\section{Metodika}

Použitá metodika standardně kombinuje terénní a laboratorní etapu. Při terénním výzkumu byl na poli v. od Dřevohostic zmapován povrchový výskyt úlomků hornin menilitového souvrství a vykopána cca $1 \mathrm{~m}$ hluboká sonda. V zastiženém odkryvu menilitového souvrství byla provedena strukturně tektonická měření geologickým kompasem a odebrány vzorky menilitových rohovců a jílovců. Ze vzorků byly na Katedře geologie PřF UP v Olomouci zhotoveny leštěné výbrusy, které byly následně studovány metodami klasické mikroskopie v procházejícím a odraženém světle pomocí polarizačního mikroskopu Olympus BX50.

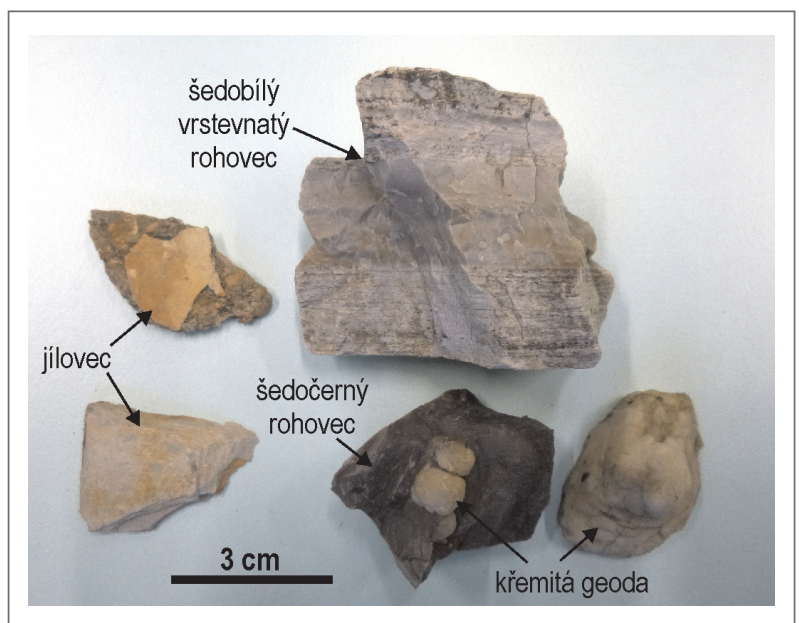

Obr. 2: Studované vzorky a odkryv menilitového souvrství: vzorky nevápnitých jílovců (vlevo), šedobílý vrstevnatý rohovec (nahoře), šedočerný rohovec uzavírající křemité geody (dole) a křemitá geoda vyplněná chalcedonem (vpravo dole).

Fig. 2: Studied samples and outcrop of the Menilite Formation: samples of non-calcareous claystones (left), gray-white laminated menilite chert (up), gray-black menilite chert with siliceous geodes (down), and a siliceous geode filled up with chalcedony (right-down). 


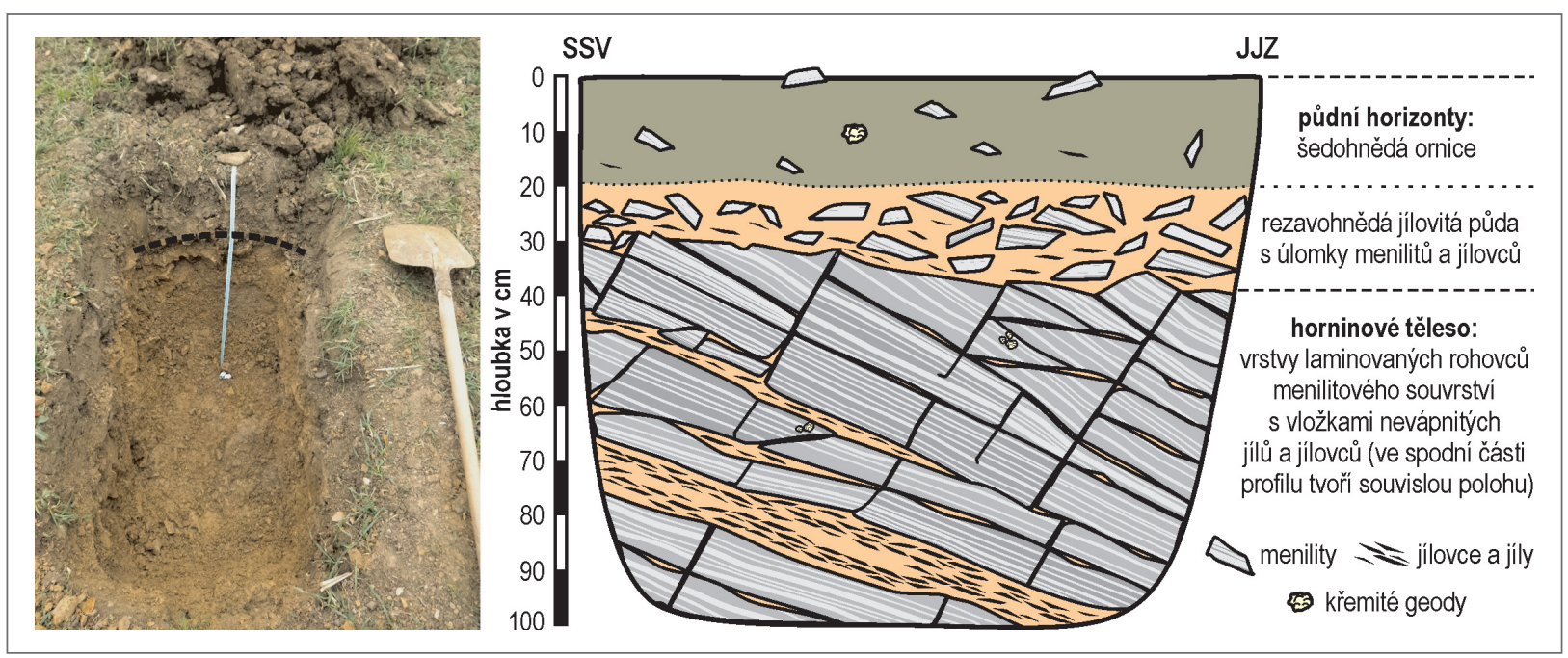

Obr. 3: Odkryv menilitového souvrství v kopané sondě: vlevo terénní fotografie (povrch výchozu rohovců označen čárkovanou linií), vpravo zjednodušené schéma profilu.

Fig. 3: An outcrop of the Menilite Formation in a test pit: field view (left) - surface of chert bedrock is marked with a dashed line and simplified section (right).

\section{Výsledky}

\section{Terénní průzkum}

Kóta 275 leží cca 1,2 km v. od zámku v Dřevohosticích. Toto území je dlouhodobě zemědělsky využíváno jako orná půda. V posledních pěti letech došlo v důsledku nevhodné výsadby kukuřice na svažitém terénu k silnému odnosu půdního pokryvu z vrcholové části kopce. Následkem toho zde dnes na ploše cca $1200 \mathrm{~m}^{2}$ hojně vystupují ostrohranné úlomky šedobílých a šedohnědých vrstevnatých menilitových rohovců (obr. 2). Na jejich př́tomnost je vázán také výskyt úlomků zvětralých šedozelených jílovců se stř́pkovitým rozpadem a také šedých křemitých krust a křemitých geod, které bývají $\mathrm{v}$ menilitech ojediněle i zarostlé. Jedná se o $1-10 \mathrm{~cm}$ velké geody s bradavičnatým povrchem šedé, bílé nebo béžové barvy a chalcedonovou výplní (obr. 2). Detailní studie křemitých geod od Dřevohostic bude zveřejněna $\mathrm{v}$ jiné práci. V podružném množství se na lokalitě vyskytují také pelosiderity a dobře opracované valounky flyšových pískovců a křemene. Pole v okolí vrcholu kopce jsou naproti tomu prakticky bez horninových úlomků. Jen velmi sporadicky lze opět narazit na zmíněné fragmenty pelosideritů, valounky pískovců a křemene (pravděpodobně kroměřížské souvrství). Zhruba ve srovnatelném množství se zde vyskytuje i materiál, který byl na pole zjevně dopraven lidskou činností (úlomky cihel, strusky, devonské amfiporové vápence, kulmské jílové břidlice a droby aj.).

Na základě nejčetnějšího výskytu menilitů bylo na plochém temeni kóty 275 vytipováno místo pro vykopání sondy. Půdní pokryv tvořený luvizemí zde eroze výrazně ztenčila. Po odkrytí pouhých $20 \mathrm{~cm}$ se barva ornice rychle mění $z$ šedohnědé na rezavohnědou až žlutohnědou. Zároveň také výrazně přibývá jílové složky a úlomků rohovců, které naznačují blízkost matečné horniny. Ta byla sondou zastižena už v hloubce cca $30 \mathrm{~cm}$ pod povrchem (obr. 3). Horninové těleso budují laminované šedobílé a šedohnědé rohovce menilitového souvrství s vložkami šedozelených až zelenohnědých jílů a jílovců, které tvoří ve spodní části profilu až $10 \mathrm{~cm}$ mocnou souvislou polohu. Menility v sobě opět vzácně uzavírají křemité geody. Vrstvy mají v celém odkryvu shodný průběh ve směru ZSZ-VJV s úklonem k JJZ pod úhlem cca $25^{\circ}$. Velikost sklonu se směrem do hloubky mírně snižuje z $30^{\circ}$ ve svrchní části profilu na $20^{\circ}$ u báze polohy jílovců. Vrstvy rohovců jsou značně rozpukány. Plochy dominujícího systému puklin mají stejný směr jako vrstevnatost horniny, ale zapadají k SSV pod strmým úhlem $55-60^{\circ}$ (obr. 3). V úrovni jednoho metru pod povrchem začala do sondy prosakovat podzemní voda a kopání bylo ukončeno.

\section{Petrografická charakteristika hornin Menilitové rohovce}

Menilitové rohovce z lokality Dřevohostice mají většinou dobře patrnou vrstevnatost v podobě střídání tenkých lamin tvořených makroskopicky šedobílým, šedým nebo šedohnědým opálem. Mocnost lamin se obvykle pohybuje v rozmezí 1-10 $\mathrm{mm}$, avšak nezřídka lze pozorovat i vrstvičky mnohem mocnější (až $3 \mathrm{~cm}$ ). Některé partie horniny jsou masivní s výrazným lasturnatým lomem a voskovým leskem (obr. 2). Povrch vzorků bývá pokryt bílou zvětralinovou kůrkou nebo rezavohnědými povlaky oxidů a hydroxidů železa, které podél trhlin zasahují také hlouběji do horniny a způsobují změnu zbarvení opálu. Stejná situace je vidět i ve výbrusech pod mikroskopem (obr. $4 \mathrm{a})$. V menilitu se střídají různě mocné vrstvičky šedého nebo žlutohnědého opálu se šmouhami rezavého limonitu a bezbarvého kryptokrystalického oxidu křemičitého (chalcedon). Opál je při pozorování se zasunutým analyzátorem opticky izotropní, zatímco chalcedon vykazuje nízký dvojlom a undulózní nebo agregátní zhášení. Trhliny o mocnosti až $0,2 \mathrm{~mm}$ porušují horninu souhlasně s vrstevnatostí, přibližně kolmo na průběh lamin i zcela nepravidelně. Jejich minerální výplň vznikala nejméně ve dvou odlišných epizodách. Starší žilky jsou tvořené 

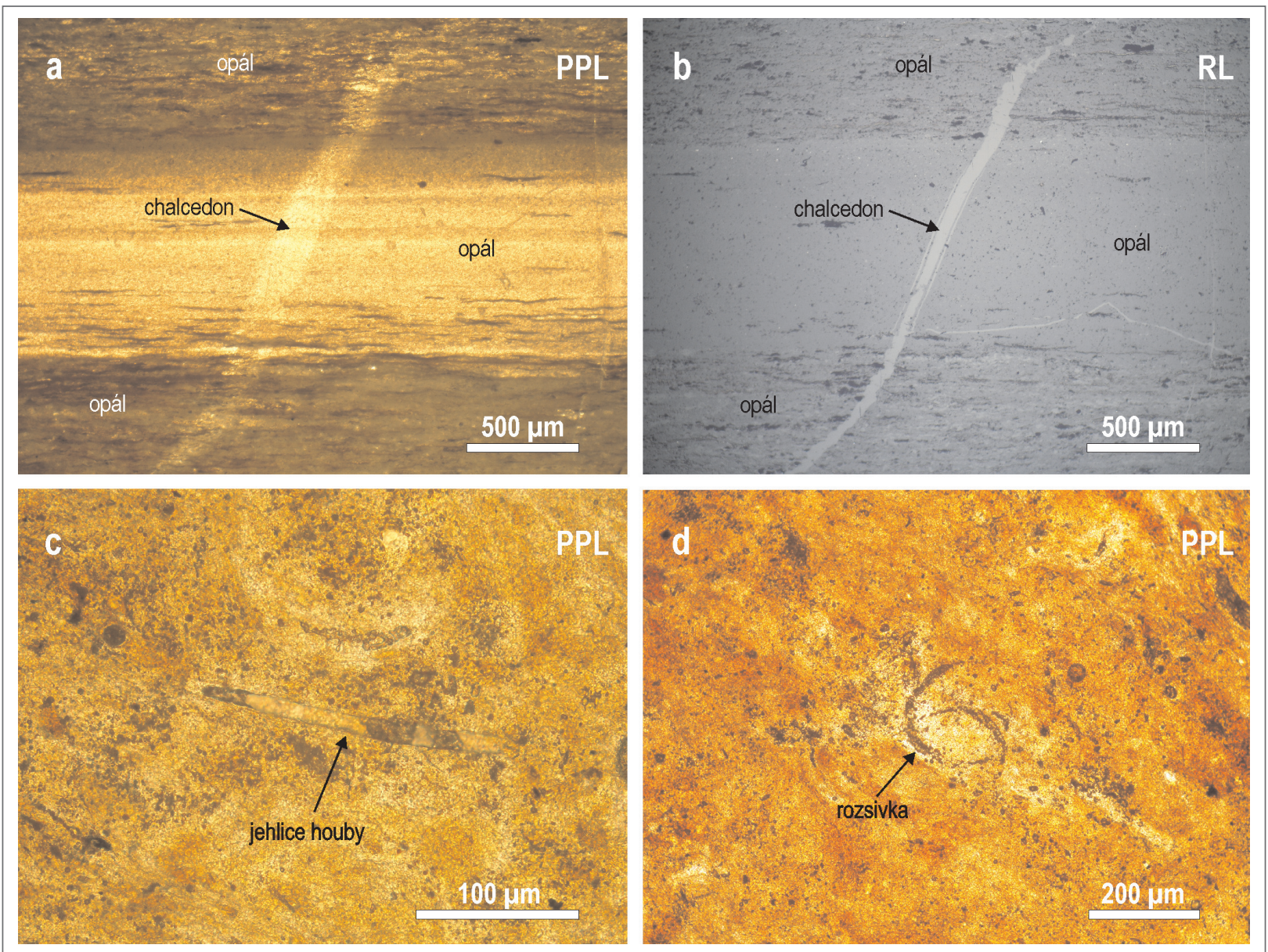

Obr. 4: Mikrofotografie výbrusů ze studovaných vzorků: a, b - menilitový rohovec tvořený laminami žlutohnědého a šedého opálu se šmouhami limonitu, vrstvy opálu proniká žilka chalcedonu ( $\mathrm{a}$ - v procházejícím světle v PPL, b - stejná situace v odraženém světle); c, d - pelitická struktura nevápnitých jílovců s chuchvalcovitou vnitřní stavbou v PPL (c - podélný průřez jehlicí kř̌emité houby, $\mathrm{d}$ - průřezy pravděpodobně planktonickými rozsivkami).

Fig. 4: Photomicrographs of thin sections from studied samples: $a, b$ - the menilite chert formed by layers of a brownish-yellow and gray opal with limonite streaks. The layers of opal are cut by vein filled up by chalcedony ( $\mathrm{a}-$ in transmitted light in PPL, b in reflected light); c, d - pelitic texture of non-calcareous claystones with a clotted inner structure containing the cross-section of a siliceous sponge spicule (c), and non-specified microfossils of probably planktonic diatoms (d).

žlutohnědým opálem a chalcedonem (obr. 4a, b). Mladší žilky vyplňují vějířovité agregáty bezbarvého chalcedonu, který tvoři až tři generace.

\section{Nevápnité jílovce}

Šedozelené až zelenohnědé nevápnité jílovce jsou silicifikované opálem a podobně jako menility výrazně zbarvené do rezava oxidy a hydroxidy železa (obr. 2). Struktura částečně zvětralé horniny je pelitická a její vnitřní stavba často nabývá chuchvalcovitého charakteru (obr. 4c, d). Jednotlivé minerální součásti nelze ani při velkých zvětšeních pod polarizačním mikroskopem bezpečně rozlišit. Pouze sporadicky se ve vzorcích vyskytují větší suboválné až subangulární klasty křemene o velikosti až $50 \mu \mathrm{m}$. Chuchvalcovité útvary jsou pravděpodobně tvořeny mikroskopickými lupínky rekrystalovaných jílových minerálů s rezavým limonitovým pigmentem, drobnými zrny křemene a opakních minerálů. V jílovcích se podařilo identifikovat prŕčné i podélné průřezy jehlicemi křemitých hub s centrálním kanálem (obr. 4c) a blíže neurčené mikrofosilie srpkovitého tvaru. S velkou pravdě- podobností by se mohlo jednat o průřezy planktonickými rozsivkami. Jejich původní schránka však byla nahrazena v procházejícím světle velmi špatně průhlednou hmotou (obr. 4d). Na základě pozorování v odraženém světle byla v této hmotě určena drobná zrnka framboidálního pyritu silně zatlačená sekundárním limonitem. Podrobnější mikropaleontologické studium nevápnitých jílů a jílovců nadále probíhá.

\section{Diskuze}

Na základě výsledků terénního průzkumu lze na kótě 275 u Dřevohostic nově vymezit menilitové souvrství na malém území o výměře cca $40 \times 30 \mathrm{~m}$. Oprávněnost vymezení dokládá dominance úlomků vrstevnatých rohovců $\mathrm{v}$ horninovém materiálu na povrchu vyplývající z přítomnosti tělesa menilitů pod mělkým půdním pokryvem. Sedimenty kroměřížského souvrství zakreslené na tomto místě v geologické mapě $1: 50000$ (Pálenský 1996) je možné dále mapovat v okolí nového výskytu menilitů, ovšem přítomnost vápnitých jílů („šlírư“) nebyla ověřena. 
Litologicky odpovídá studovaný sled vrstevnatých rohovců s vložkami nevápnitých jílovců rohovcovým vrstvám ve smyslu členění menilitového souvrství ve ždánické jednotce. O menilitových rohovcích se soudí, že vznikly diagenetickou přeměnou diatomitů v hloubkách středního až spodního batyálu (Krhovský 1981; Stráník, $\mathrm{v}$ tisku). Po vzniku menilitů došlo v litifikovaných rohovcích k vytvoření drobných trhlin a dutin, které byly vyhojeny opálem a mladším chalcedonem nejméně během dvou různých epizod.

Současná geologická pozice tělesa menilitových rohovců u Dřevohostic je dána vyvrásněním podslezského př́krovu a jeho nasunutím na karpatskou předhlubeň v miocénu. Směr vrstev menilitů a jílovců (ZSZ-VJV) neodpovídá průběhu karpatského oblouku (resp. flyšového pásma). Karpatský směr je typický pro vrstevnatost sedimentárních těles račanské, předmagurské a slezské jednotky v Hostýnských vrších i v j. části Kelčské pahorkatiny (Roth et al. 1962; 1963). V př́padě podslezské jednotky ve studované oblasti je však tektonická situace poněkud komplikovanější nejen kvůli nedokonalému odkrytí v terénu. Podslezský př́krov byl ke konci karpatu přesunut přes autochtonní podloží nejméně o $20 \mathrm{~km}$ k S až SZ do blízkosti kry Maleníku. Jednotlivé vrstvy byly rozčleněny do šupin, často detailně provrásněny až prohněteny a následně intenzívně tektonicky porušeny mladoštýrskými rotačními pohyby s vergencí k SZ (Roth et al. 1962; Krs et al. 1977; Eliáš 1998). Srovnatelný směr vrstev jako horniny menilitového souvrství u Dřevohostic mají např. i nadložní psefiticko-psamitické sedimenty mezi Býškovicemi a Malhoticemi (Roth et al. 1963).

\section{Závěry}

Na kótě 275 v. od Dřevohostic se podařilo zmapovat nový výskyt rohovcových vrstev menilitového souvrství na území o rozloze cca $1200 \mathrm{~m}^{2}$. Menilitové souvrství je zde tvořeno šedobílými a šedohnědými laminovanými rohovci s drobnými polohami šedozelených až zelenohnědých nevápnitých jílovců, které sporadicky obsahují jehlice křemitých hub a další mikrofosilie (pravděpodobně planktonické rozsivky). Úložné poměry horninového tělesa byly ověřeny kopanou sondou. Vrstvy mají směr ZSZ-VJV a zapadají k JJZ pod úhlem $20-30^{\circ}$. Sedimenty byly zvrásněny během nasouvání podslezského příkrovu na karpatskou výplň předhlubně a pravděpodobně také během následných mladoštýrských rotačních pohybů sz. vergence.

\section{Poděkování}

Kolektiv autorů by rád poděkoval bývalému starostovi Dřevohostic panu Stanislavu Skýpalovi za laskavé svolení $s$ provedením terénních prací na obecním pozemku $v$ oblasti kóty 275. Zároveň bychom rádi poděkovali oponentům Miroslavu Bubíkovi a Daliboru Matýskovi a editorce Pavle Tomanové Petrové za cenné rady a pripomínky, které přispěly ke zkvalitnění publikace. Práce byla podpořena projektem IGA PrF_2014019. 


\section{Literatura}

Adámek, J. - Brzobohatý, R. - Pálenský, P. - Šikula, J. (2003): The Karpatian in the Carpathian Foredeep (Moravia). - In: Brzobohatý, R. - Cicha, I. - Kováč, M. - Rögl, F. (eds.): The Karpatian, A Lower Miocene Stage of the Central Paratethys, 75-88, Masarykova univerzita.

Benada, S. - Kokolusová, A. (1987): Nové poznatky o geologické pozici hrubých klastik karpatu ve střední části karpatské předhlubně na Moravě. - Zemní plyn a nafta, 32, 1, 1-15.

Brzobohatý, R. - Kalabis, V. (1978): Biostratigrafické korelace v paleogénu a neogénu na základě ichtyofauny. - Zemní plyn a nafta, 23, 4, 533-542.

Čtyroký, P. - Fejfar, O. (1963): Fauna písků a pískovců karpatské formace u Dolních Nětčic v Karpatské čelní hlubině. - Geologické práce, Správy, 27, 143-168.

Eliáś, M. (1998): Sedimentologie podslezské jednotky. - Práce Českého geologického ústavu, 8, 4-48.

Gregorová, R. (1988). Rybí fauna menilitového souvrství na lokalitě Litenčice a její stratigrafická pozice. - Acta Musei Moraviae, Scientiae naturales, 73, 83-88.

Hanzlíková, E. - Menčík, E. - Pesl, V. (1953): Poznámky ke stratigrafii a tektonice subslezského příkrovu na listu Nový Jičín. Zprávy o geologických výzkumech v roce 1952, 15-18.

Jurková, A. (1976): Stavba karpatské předhlubně a flyšových příkrovů na sv. Moravě. - Časopis pro mineralogii a geologii, 21, 4, $349-362$.

Kalabis, V. (1981): Historický přehled studia ichtyofauny středních třetihor Moravy. - Zemní plyn a nafta, 26, 1, 75-78.

Kropáč, K. - Dolníček, Z. - Přichystal, A. - Koštuř́́ková, T. (2014): Křemité geody z okolí Dřevohostic na Přerovsku. - Minerál, $22,6,355-357$.

Krhovský, J. (1981): Mikrobiostratigrafické korelace vnějších jednotek flyšového pásma a vliv eustatických změn na jejich paleogeografický vývoj. - Zemní plyn a nafta, 26, 4, 665-683.

Krs, M. - Krsová, M. - Roth, Z. (1977): A paleomagnetic study of Cenomanian-Lower Turonian sediments in the Moravskoslezské Beskydy Mts. - Věstník Ústředního ústavu geologického, 52, 6, 323-332.

Pálenský, P. (1996): Geologická mapa ČR 1 : 50 000, list 25-13 Přerov. - Český geologický ústav. Praha.

Přikryl, T. (2009): A juvenile Trachinus minutus (Pisces, Perciformes, Trachinidae) from the Middle Oligocene of Litenčice (Moravia, Czech Republic). - Sborník Národního muzea v Praze, Řada B - Př́rodní vědy, 65, 1-2, 3-8.

Roth, Z. - Cicha, I. - Demek, J. - Eliáš, M. - Frajarová-Eliášová, H. - Hanzlíková, E. - Jetel, J. - Mencl, V. - Mísařr, Z. - Pašek, J. - Paulík, J. - Pícha, F. - Plička, M. - Polák, A. - Šalanský, K. - Šamalíková, M. - Šimek, R. - Šmíd, B. - Tyráček, J. Unzeitig, M. (1962): Vysvětlivky k přehledné geologické mapě ČSSR 1 : 200000 M-33-XXIV Olomouc. - Nakladatelství Československé akademie věd. 226 str.

Roth, Z. - Dvořák, J. - Kettner, R. - Paulík, J. (1963): Geologická mapa ČSSR 1 : 200000 M-33-XXIV Olomouc. - Ústřední ústav geologický. Praha.

Stráník, Z. (1981): Litofaciální vývoj a korelace menilitových vrstev ve flyšovém pásmu Karpat na Moravě. - Zemní plyn a nafta, $26,1,9-18$.

Stráník, Z. (v tisku): Flyšové pásmo. - In: Stráník, Z. (ed.), Adámek, J. - Brzobohatý, T. - Buchta, Š. - Dudek, A. - Grygar, R. - Otava, J. - Pálenský, P. - Tyráček, J.: Geologie Karpat a jihovýchodního okraje západoevropské platformy v České republice. - Česká geologická služba.

Stráník, Z. - Menčík, E. - Eliáš, M. - Adámek, J. (1993): Flyšové pásmo Západních Karpat, autochtonní mesozoikum a paleogén na Moravě a ve Slezsku. - In: Přichystal, A. - Obstová, V. - Suk, M. (eds.): Geologie Moravy a Slezska, 107-122, Moravské zemské muzeum a Masarykova univerzita. 